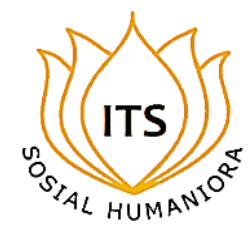

\title{
Toleransi Antarumat Beragama di Indonesia dari Perspektif Etika Kepedulian
}

\section{Yeremias Jena}

Fakultas Kedokteran dan Ilmu Kesehatan, Universitas Katolik Indonesia Atma Jaya, Jakarta, 14440, Email: yeremias.jena@atmajaya.ac.id

Diterima: $24 / 09 / 2019$

Direview: 22/10/2019

Diterbitkan: 30/12/2019

Hak Cipta @ 2019 oleh Penulis (dkk) dan Jurnal Sosial Humaniora (JSH)

*This work is licensed under the Creative

Commons Attribution International License (CC BY 4.0).

http://creativecommons.org/licenses/by/4.0/

Open Access

\section{Subject Area: Philosophy (Filsafat)}

\section{Abstract [in ENGLISH]}

Dialogue and co-existence between religious believers have been practiced quite extensively in Indonesia, especially since the New Order era. From the beginning, it did happen top-down because of the government's political strategy to create a peaceful and stable society for the success of physical development. However, in subsequent developments, the importance of changing approaches to dialogue and cooperation between religious believers was considered as an urgent matter. Therefore, the active involvement of citizens and the creation of social spaces for the interaction and encounter of citizens of different religions, ethnicities and cultures have been initiated and practiced by the government in many regions of Indonesia. Unfortunately, intolerant and exclusive attitudes among citizens still occur. By using philosophical inquiry methods to analyze various practices of interreligious dialogue in Indonesia, it was found that first, there has been a change in approach in interreligious dialogue in Indonesia. Second, it is increasingly being realized that social spaces for encounters between different citizens must continue to be expanded as a medium to combat intolerant attitudes. Third, caring ethics, especially aspects of attention, can be a moral and philosophical foundation that strengthens caring interactions between citizens in the social space that has been formed.

Keywords: — inter-religious dialogue; encounter; tolerance; attention; ethics of care.

\section{Pendahuluan}

Dialog antarumat beragama memang belum dilaksanakan secara masif selama masa Orde Lama selain upaya agama-agama (terutama Islam) untuk meredam kebijakan politik Nasionalisme-Komunisme Soekarno justru cenderung membenturkan agama dengan komunisme (Mantu, 2018; Anwar, 2018). Baru menjelang awal tahun 1970-an, ketika kekerasan antaragama terjadi di beberapa daerah di Indonesia, dialog dan kerja sama antarumat beragama dipraktikkan dengan sungguh-sungguh oleh rezim Orde Baru, meskipun pendekatan yang dipilih masih bersifat pragmatis dan top-down yang hanya bertujuan untuk menjaga stabilitas dan pembangunan nasional (Ismail, 2016). Pembentukan Forum Kerukunan Umat Beragama (FKUB) tahun 2006 adalah kesempatan untuk menghimpun kekuatan umat beragama untuk bersama-sama mengusahakan kehidupan bersama yang toleran. Mengikutsertakan masyarakat dalam proses dialog antarumat beragama selama Orde Baru adalah tanda terjadinya perubahan pendekatan, terutama dari semula yang bersifat top-down kepada sebuah gerakan kewargaan (Sirait, 2017; Sultoni \& Darojat Ariyanto, 2017; Casram, 2016). 
Di balik perkembangan yang sangat positif, fenomena intoleransi selama Orde Baru terus saja terjadi (lihat misalnya Mudzakkir, 2017; Sholikin, 2018); Wahid et al., 2015). Hal inilah yang nantinya akan meninggalkan masalah toleransi di kemudian hari. Di satu pihak, ada usaha sistematis sejak Orde Baru untuk memajukan toleransi antarumat beragama, tetapi di lain pihak, sikap intoleran semakin menggejala di masyarakat. Luthfi Assyaukanie mencatatat bahwa problem intoleransi berakar pada pasal-pasal aturan perundang-undangan di Indonesia tentang kehidupan beragama yang semula dimaksudkan untuk melindungi warga negara tetapi justru berbalik menjadi alat "penindas" kelompok dan/atau orang tertentu (Assyaukanie, 2018; lihat juga Ali, Hum, Kastolani, \& Ag, 2019; Irham, 2017).

Berbagai upaya telah dilakukan untuk memajukan dialog dan kerja sama antarumat beragama, namun mengapa intoleransi masih saja terjadi? Telah ada banyak penelitian yang menjawab pertanyaan ini. Mengikuti pembacaan macam-macam dialog antarumat beragama yang pernah digagas Mukti Ali (Anwar, 2018), sebenarnya dialog kehidupan yang membuka ruang perjumpaan dan pengalaman real berinteraksi anatarumat beragama sudah banyak diusahakan.

Pembacaan yang cermat atas berbagai literatur itu tampak menegaskan pentingnya pembauran sebagai conditio sine qua non bagi keberhasilan toleransi antarumat beragama. Pembauran sebagai keutamaan sosial hanya mungkin terjadi jika orang mau keluar dari zonanya, mulai berinteraksi dengan orang lain yang berbeda dan mengalami perbedaan itu secara personal (Ali et al., 2019). Pendapat ini diafirmasi oleh publikasi lain yang menegaskan pentingnya menciptakan ruang yang semakin luas bagi perjumpaan nyata warga negara yang berbeda agama, suku, dan budayanya (Hakim Saifuddin et al., 2019; Naim, 2016). Berbagai pemberitaan dan opini yang Peneliti analisis dalam data Harian Kompas selama periode 1965-2019 juga mengafirmasi pendapat ini.

Di balik banyaknya publikasi yang menekankan pentingnya perjumpaan real antarumat beragama, para peneliti sering berbicara mengenai sikap-sikap yang dibutuhkan bagi terwujudnya dialog antarumat beragama. Tentang itu, sikap-sikap saling menghormati, kesetaraan, tidak mewartakan agama kepada sesama warga yang telah beragama, terbuka, kesediaan bekerja sama, keberanian keluar dari zona nyaman, dan semacamnya telah banyak dibicarakan (Irham, 2017; Anwar, 2018).

Peneliti beragumen bahwa sikap-sikap seperti ini harus terus dikampanyekan dalam ruang perjumpaan antarwarga yang berbeda agama. Dalam upaya mempertegas sekaligus memperkaya sikap-sikap yang dibutuhkan dalam dialog dan kerja sama antarumat beragama inilah Peneliti menawarkan gagasan inti etika kepedulian, dalam dimensi perhatian (attention). Dialog dan kerja sama antarumat beragama wajib dilaksanakan dalam masyarakat Indonesia yang sangat plural. Berbagai pendekatan perlu dipertimbangkan secara matang sebelum melibatkan warga negara dalam dialog dan kerja sama

\section{Tinjauan Pustaka}

Dialog antarumat beragama telah menjadi sarana untuk mewujudkan toleransi antarumat agama. Di Indonesia, dialog itu termanifestasi secara lebih terorganisir dan institusional sejak tahun 1969. Secara pragmatis, campur tangan pemerintah menghentikan konflik antaragama dan mendorong dialog antara pihak 
terkait mengafirmasi pentingnya dialog dan kehidupan bersama yang harmonis sebagai kondisi niscaya bagi pelaksanaan pembangunan di Indonesia (Banawiratma \& Bagir, 2010). Meskipun bukan yang paling tepat, langkah pragmatis tetap dibutuhkan untuk menjamin tersedianya eksistensi yang setara bagi setiap kelompok sosial.

Hal ini tampak nyata dalam bagaimana pemerintah Indonesia di bawah Kementerian Agama terus mempromosikan dialog antarumat beragama pasca G 30 S/PKI. Inilah langkah politik menjamin kehidupan bersama warga masyarakat yang berbeda latar belakang agama, suku, etnik dan budaya. Dialog dan kerja sama telah menjadi salah satu kebijakan politik terutama pada masa pemerintahan Soeharto. Pemerintahan Soeharto mewajibkan setiap warga negara "...melupakan perbedaan dan lebih berfokus pada kepentingan bersama, yakni pembangunan" dengan mengambil pendekatan "dari atas ke bawah (top down) sebagai model. Dialog antarumat beragama, terutama Islam dan Kristen pasca G30S/PKI diwarnai oleh "kecurigaan" atas isu Kristenisasi. Banyaknya etnis Tionghoa yang menjadi Kristen tidak hanya dianggap sebagai Kristenisasi, tetapi juga sebagai upaya Gereja Kristen melindungi para pengikut dan simpatisan komunis. Pembakaran gereja di Meulaboh tahun 1967 dan beberapa pemuda Muslim di Makassar merusak sekitar 20 gereja pada tahun 1967 adalah contoh kecurigaan tersebut (Banawiratma \& Bagir, 2010). Jika peran mempromosikan toleransi antarumat beragama di era Orde Lama ada di tangan kerukunan antarumat beragama, selama Orde Baru dijalankan oleh Wadah Musyawarah Antar-Umat Beragama (WMAUB) dan Lembaga Pengkajian Kerukunan Umat Beragama (LPKUB). Sementara itu, Orde Reformasi memberi ruang yang luas bagi gerakan toleransi pada akar rumput dengan menekankan pengembangan wawasan multikultural (Banawiratma \& Bagir, 2010).

Orde Reformasi memang ditandai oleh keterbukaan di segala bidang kehidupan, misalnya partisipasi warga negara dalam praktik demokrasi dan pemerintahan serta penyelenggaraan negara yang terdesentralisasi di level kabupaten. Peran pemerintah daerah dalam mewujudkan kerukunan antarumat beragama pun diberi tempat dengan penekanan pada upaya memajukan kehidupan bersama yang multikultural. Meskipun demikian, konflik antarumat beragama tampaknya belum berhasil diredam. Beberapa konflik dan kekerasan yang menonjol dapat dapat disebutkan sebagai contoh.

Setelah peristiwa berdarah Trisakti, Semanggi 1 dan Semanggi 2 yang menandai peralihan Orde Baru ke Orde Reformasi, Indonesia menghadapi konflik rasial yang menelan banyak korban. Misalnya, konflik Ambon tahun 1999, Poso selama tahun 2000-2001, dan Sampit (Kalimantan Tengah) tahun 2000-2001. Selain itu, selama kurun waktu 2008-2016, Komisi Nasional Hak Asasi Manusia mencatat banyak kasus kekerasan melawan kebebasan beragama, antara lain kekerasan terhadap pengikut Ahmadiyah, kasus Mushala AsySyafiiyah di Denpasar tahun 2008, pengusiran ribuan anggota Gafatar tahun 2016, pembakaran Gereja Huria Kristen Indonesia di Aceh Singkil tahun 2016. Termasuk juga kekerasan terhadap warga Syiah di Sampang tahun 2012, bentrok warga dengan jemaat Huria Kristen Batak Protestan HKBP Filadelfia di Bekasi tahun 2012, larangan beribadah bagi umat Kristen Protestan dalam kasus Gereja Yasmin di Bogor tahun tahun 2010, serta kerusuhan agama di Tolilkara tahun 2015 (Erdianto, 2018). 
Bagi Christian Solidarity Worldwide (CSW), berbagai konflik horizontal ini menunjukan bahwa "pluralisme Indonesia sedang menyongsong maut", setidaknya karena dua alasan utama. Pertama, selain gagal dalam membela rakyat dari ancaman kekerasan kelompok radikal, pemerintah juga tidak tegas menegakkan hukum atas para pelaku. Sikap tidak tegas ini akan membuka ruang bagi "pengarusutamaan kekerasan" sampai pada titik di mana gejala itu diterima sebagai lumrah (Erdianto, 2018).

Kedua, telah terjadi apa yang disebut Masdar Hilmy sebagai "diseminasi narasi intelektual tidak cukup kuat membendung penyebaran pemikiran intoleran, dan itu membahayakan filsafat tradisional orang Indonesia yang menghormati keanekaragaman.” Eksistensi berbagai jaringan dan institusi yang membendung gerakan ekstrimis-fundamentalis semisal Wahid Institute, Maarif Institute, International Center for Islam and Pluralism atau Jaringan Islam Liberal tampak berjuang sendiri tanpa dukungan memadai pemerintah (Rogers \& Flipse, 2014).

Absennya negara melindungi warga negaranya dan longgarnya penegakan hukum relatif lebih mudah diatasi. Melalui berbagai protes massa, desakan dari berbagai elemen masyarakat, atau protes keras berbagai lembaga internasional, peran pemerintah melindungi segenap rakyat Indonesia dapat dikembalikan. Tetapi tidak demikian dengan sikap intoleran yang telah menghabituasi sehingga perlahan-lahan dianggap sebagai hal yang wajar.

Dalam konteks inilah kita dapat membaca temuan Pusat Data dan Statistik Pendidikan dan Kebudayaan (PDSPK) Kementerian Pendidikan dan Kebudayaan sebagai fakta yang meresahkan (Pusat Data dan Statistik Pendidikan dan Kebudayaan, 2017). Analisis terhadap data Survei Sosial Ekonomi Nasional (SUSENAS 2014) yang melibatkan 300 ribu responden (SUSENAS, 2014) di seluruh Kabupaten/Kota di Indonesia menunjukkan 42,4 persen warga bersikap cukup toleran (sangat setuju dan setuju) terhadap kegiatan yang dilakukan kelompok agama lain di sekitar lingkungan tempat tinggalnya. Sisanya, yakni 57,6 persen memiliki sifat yang kurang toleran (tidak setuju dan kurang setuju).

Data SUSENAS 2014 juga menunjukkan bahwa status sosial ekonomi, usia, pekerjaan, jenis kelamin, karakteristik tempat tinggal, dan tingkat pendidikan ikut memengaruhi sikap toleransi seseorang. Tingkat toleransi semakin meningkat sejalan dengan membaiknya kehidupan ekonomi warga. Sebanyak 63,8 persen kelompok keluarga miskin memiliki sikap yang kurang toleran terhadap kelompok agama lain. Sikap toleran semakin meningkat pada masyarakat kelas ekonomi menengah, di mana 40,8 persen cukup toleran dibandingkan dengan 59,2 persen yang kurang toleran. Sementara itu, terdapat 52,3 persen yang kurang toleran dibandingkan dengan 47,7 persen kelompok kaya yang cukup toleran. Data ini masih berkolerasi dengan 59,0 persen sikap kurang toleran dibandingkan dengan 41 persen sikap cukup toleran pada kelompok masyarakat yang tidak bekerja. Di kelompok masyarakat yang bekerja, terdapat 57 persen warga memiliki sikap kurang.

Di kalangan kelompok terdidik, terdapat 58 persen warga yang memiliki sikap cukup toleran. Sebaliknya, di kalangan kelompok masyarakat berpendidikan menengah dan rendah, terdapat 43,3 persen warga memiliki sikap cukup toleran. Sementara itu, di kalangan masyarakat yang tidak memiliki ijazah, terdapat 35,8 persen warga bersikap cukup toleran. Sikap pluralistik dan toleran lebih dimiliki oleh warga yang 
tinggal di perkotaan, yakni sebesar 47,1 persen. Sementara itu, perempuan memiliki sikap kurang toleran yang mencapai 58,8 persen dibandingkan dengan laki-laki.

\section{Metode Penelitian}

Penelitian ini menggunakan metode inkuiri filosofis (philosophical inquiry). Metode inkuiri filosofis digunakan karena Peneliti untuk menjawab berbagai problem filosofis yang ditimbulkan oleh praktik toleransi antarumat beragama di Indonesia. Suatu fenomena disebut mengandung problem filsofis jika berhubungan dengan Tuhan atau realitas mutlak (metafisik), kebenaran (epistemologi), etika dan moralitas, kebebasan, tanggung jawab (aksiologis), dan sebagainya (Creel, 2001).

Dalam penelitian ini, Peneliti memusatkan perhatian pada proses analisis konseptual. Maksudnya adalah masalah-masalah filosofis yang ditemukan dalam inkuiri filosofis dipecahkan dengan menggunakan contohcontoh paradigmatik, tepatnya konsep-konsep filosofis yang tersedia dan yang relevan dengan fenomena. Contoh paradigmatik atau konsep-konsep ini digunakan untuk mendefinisikan dan mengklarifikasi maknamakna, term-term, atau konsep-konsep tertentu, mengurai ketidakcukupannya dan mengusulkan konsepkonsep lain yang lebih memadai. Hasil akhir yang diharapkan dari ini adalah sebuah pemahaman baru yang lebih mendalam dan komprehensif (Magrini, 2018).

Praktik toleransi antarumat beragama di Indonesia sejak zaman Orde Lama diposisikan sebagai fenomena. Pertama-tama Peneliti berusaha memahami praktik toleransi itu secara deskriptif. Inilah pertanyaan pertama yang Peneliti jawab: apakah ada toleransi di Indonesia, dan jika ada, seperti apakah praktik toleransi itu? Setelah itu, Peneliti menjawab pertanyataan kedua: jika toleransi antarumat beragama di Indonesia sudah dipraktikkan, mengapa masih terjadi konflik dan pertentangan antarumat beragama? Apakah ada hal yang keliru secara sistem atau secara konseptual? Pertanyaan terakhir yang Peneliti jawab adalah jika ruang perjumpaan nyata sebagai syarat mutlak bagi terwujudnya toleransi antarumat beragama sudah tersedia di masyarakat tetapi konflik dan pertentangan antarumat beragama masih terjadi, apakah ada kondisi-kondisi yang lebih primordial yang seharusnya dipenuhi terlebih dahulu? Dalam mengusulkan jalan keluar konseptual bagi problem toleransi antarumat beragama, Peneliti menawarkan etika kepedulian sebagai konsep filosofis (contoh atau rujukan paradigmatik).

Tentang tersedianya ruang perjumpaan yang real (pertanyaan ketiga), Peneliti melakukan penelitian atas data publikasi Harian Kompas di laman data Harian Kompas (http://www.kompasdata.id/). Ini adalah penelitian deskriptif menggunakan kata kunci "perjumpaan dan toleransi” pada mesin pencari data di laman tersebut. Penelitian ini diambil untuk mengafirmasi hipotesis bahwa ruang perjumpaan yang real adalah kondisi niscaya bagi terwujudnya kehidupan yang damai dan toleran antarumat beragama.

\section{Hasil dan Pembahasan}

Telah ada upaya sistematis melalui berbagai inisiatif dan peraturan perundang-undangan untuk memajukan toleransi antarumat beragama. Juga semakin disadari bahwa toleransi dan kerja sama antarumat beragama sulit terwujud tanpa perjumpaan real antarumat beragama. Penelitian ini mengafirmasi pentingnya 
memperbanyak ruang perjumpaan. Ruang perjumpaan real antarumat beragama hendaknya direalisasikan dengan mempertimbangkan secara serius prinsip etika kepedulian.

\section{Perbanyak Ruang Perjumpaan}

Tema perjumpaan sebagai basis material bagi toleransi antarumat beragama sudah sering dibicarakan, terutama dalam berbagai opini lepas dan wawancara media massa; dan sekarang semakin disadari urgensinya. Sekadar mencari berita seputar "perjumpaan dan toleransi" secara verbatim di mesin pencari google selama enam bulan terakhir, misalnya ditemukan hampir dua ribu data tersaji. Pengamatan awal semacam ini menegaskan pentingnya "perjumpaan" sebagai syarat terwujudnya kehidupan rukun antarumat beragama.

Sekadar menyebut contoh, kegiatan perkemahan yang diinisiasi Forum Kerukunan Umat Beragama (FKUB) yang melibatkan generasi muda dari berbagai agama di daerah Kulon Progo, DI Yogyakarta adalah momentum perjumpaan antarindividu yang berbeda agama (Fadel, 2019; Banawiratma \& Bagir, 2010). Berbagai kegiatan serupa menegaskan pendapat ahli/pengamat, bahwa "toleransi itu dipupuk bukan dari banyak pembicaraan, tetapi perjumpaan nyata, saat ada tukar-menukar informasi, ada saling pengertian dan kerja sama dengan semangat gotong royong. Kecendrerungan hidup secara homogen dan eksklusif nyata dalam pemukiman dan perumahan bersyariah (Amindoni, 2019; Syambudi, 2019). Ridwan Lubis berargumentasi bahwa berbagai daerah di Indonesia memiliki dinamika perkembangan umat dan problem relasi antarumat yang khas sehingga dibutuhkan penanganan yang berbeda pula. Sejauh ini, daerah-daerah tersebut (secara khusus disebutkan Kepulauan Riau, Dayak, Sulawesi Tenggara, Bali, NTT, dan Jawa Barat) memiliki dinamika interaksi antarpemeluk agama yang cukup positif, kecuali Jawa Barat yang dinilai kurang toleran (Lubis, 2016).

Untuk mendapatkan data pendukung seputar urgensi perjumpaan bagi dialog antaragama, Peneliti melakukan penelitian atas tema tersebut pada data Harian Kompas (http://www.kompasdata.id/) selama tanggal 1-21 Agustus 2019. Dengan memasukkan kata kunci "perjumpaan dan toleransi” tanpa rentang waktu tertentu didapatkan 113 entry data yang tersebar di Jakarta (36) dan luar Jakarta (77). Ringkasan dari semua entry data itu kemudian disalin ke dalam kolom yang tersedia berdasarkan kolom (1) nomor data, (2) uraian, (3) apakah berita tersebut membicarakan secara khusus tema yang dimintakan ("Ya") atau tidak membicarakannya ("Tidak"). Lembar entry data dibaca ulang satu per satu secara menyeluruh.

Peneliti kemudian menganalisis apakah setiap berita itu membicarakan secara khusus tema "perjumpaan dan toleransi" atau tidak. Peneliti membubuhi tanda check list pada kolom "Ya" jika berita tersebut membicarakan tema "perjumpaan dan toleransi", dan tanda silang X pada kolom "Tidak". Hasil penelitian ini dapat dilihat pada Tabel berikut.

\begin{tabular}{lccc}
\hline Kata Kunci & Total Data & "Ya" & "Tidak" \\
\hline "perjumpaan dan toleransi" & 113 & 35 & 78 \\
& & & \\
\hline
\end{tabular}


Sebanyak 35 artikel berita yang membicarakan tema "perjumpaan dan toleransi" dapat dikelompokkan ke dalam 5 tema, yakni (1) soal rumah ibadah dan perayaan keagamaan sebagai tempat dan momentum bagi perjumpaan, (2) pentingnya merancang ruang publik (disebutkan secara khusus tempat wisata, desa, kota, termasuk juga sekolah) sebagai tempat perjumpaan, (3) pentingnya teladan (modelling) atau tokoh panutan bagi perjumpaan dan toleransi (disebut secara eksplisit peran tokoh agama dan peran guru-guru di sekolah), (4) inisiatif kelompok masyarakat dalam membangun ruang bagi terjadinya perjumpaan, dan (5) dukungan kebudayaan dengan aneka simbolnya bagi perjumpaan dan toleransi.

Seluruh perbincangan mengenai "perjumpaan dan toleransi" dalam berita-berita yang Peneliti analisis tersebut menegaskan tiga hal berikut. Pertama, toleransi antarumat beragama haruslah merupakan pengalaman konkret perjumpaan, pengalaman dalam ruang dan waktu tertentu di mana orang berinteraksi dengan orang lain yang berbeda agama. Perjumpaan itu dapat terjadi di rumah ibadah, di sekolah, di ruang-ruang publik yang sengaja diciptakan untuk membangun perjumpaan antarpemeluk agama, atau bahkan di ruang-ruang publik umum seperti tempat wisata, desa, kota dan sebagainya.

Ruang publik yang dirancang secara sengaja untuk memfasilitasi perjumpaan antarwarga yang berbeda agama dapat dilihat, misalnya di Fakfak dengan filosofi "satu tungku tiga batu", bukit doa Puja Mandala di Nusa Dua Bali, laboratorium kemajemukan di Semarang, dan di banyak daerah lainnya. Ini juga sejalan dengan rancangan taman-taman di Kota Surabaya sebagai tempat bertemu dan berinteraksinya warga yang berbeda suku, agama dan budaya (Jena, 2016). Ridwan Lubis mengusulkan penciptaan ruang publik dan tata kelola ruang fisik kehidupan bersama sebagai lokus perjumpaan antarumat beragama (Lubis, 2016).

Kedua, masyarakat membutuhkan teladan (model) perjumpaan dan toleransi. Di satu pihak, ada ekspresi ketidaksenangan terhadap guru-guru di sekolah atau tokoh-tokoh agama yang kurang memberi ruang pada perjumpaan antarmanusia. Di lain pihak, beberapa tokoh agama yang aktif mengunjungi tokoh dan/atau umat beragama lain dirujuk sebagai model perjumpaan. Misalnya, kunjungan Paus Fransiskus ke Turki dan seruan perdamaian dari dalam sebuah masjid serta kunjungan Presiden Iran, Hassan Rouhani ke Vatican. Perjumpaan itu merajut kesadaran sebagai sesama anak Allah (Kuncahyono, 2016). Perjumpaan antarpemeluk agama yang berbeda juga menjadi momen penghayatan spiritualitas yang mendalam antarumat beragama (Harian Kompas, 13 Agustus 2000).

Ketiga, unsur-unsur budaya Indonesia dengan kekayaan simbol-simbolnya telah menjadi "penjaga" kebersamaan. Unsur dan simbol kebudayaan ini wajib dijaga, dipertahankan, dan dikembangkan lebih lanjut. Unsur-unsur budaya itu telah eksis bahkan jauh sebelum kedatangan agama-agama monoteis di bumi Nusantara, dan itu yang menjadi simbol pemersatu warga. Tentang hal ini, catatan Teuku Kemal Fasya tentang eksistensi tiga gereja di Kampong Mulia Banda Aceh yang mayoritas penduduknya beragama Islam menarik untuk diperhatikan. “.... Masyarakat yang lama berkhimad dalam keberagaman sebenarnya memiliki daya untuk membangkitkan energi perjumpaan sosial-ekonomi-kultural secara kreatif. Potret mayoritas-minoritas tidak pernah menebal menjadi suatu konflik di dalam masyarakat seperti itu. Relasi mayoritas-minoritas terkaburkan oleh sikap saling memerlukan dan bergantung" (Kemal Fasya, 2016). 
Perjumpaan tidak hanya didorong untuk terjadi, tetapi juga diperbanyak. Sebagai salah satu dari tiga aktor yang dapat mengusahakan dialog antarumat beragama, masyarakat diharapkan berperan aktif mengusahakan perjumpaan itu, selain juga peran pelaku usaha (pasar). Ketiga aktor itu bahkan menjalankan perannya secara saling berkelindan (Banawiratma \& Bagir, 2010). Tentang peran yang harus dijalankan oleh masing-masing aktor dalam mengusahakan ruang perjumpaan dan dialog antarpemeluk agama, Banawiratma dkk (Banawiratma \& Bagir, 2010) menegaskan pentingnya keberpihakan pada paradigma "kita" sebagai cara pandang holistik yang melihat ruang publik sebagai tempat perjumpaan berbagai orang yang berbeda. Paradigma "kita" juga dipahami sebagai fondasi bagi terbentuknya rasa bagi keseluruhan sebagai kondisi untuk memberangus eksklusivisme.

Kalaupun telah tersedia ruang perjumpaan dan kesempatan untuk berinteraksi secara intensif, paradigma "kita" atau kesadaran sebagai saudara tidak dengan sendirinya terbentuk. Ada kondisi tertentu yang harus dipenuhi demi terbentuknya kesadaran "kekitaan", rasa solidaritas antarwarga, dan ikatan batin sebagai saudara. Kajian-kajian ilmu sosial dapat dirujuk untuk menjelaskan kondisi-kondisi yang diprasyaratkan bagi terbentuknya kesadaran "kekitaan", dan Peneliti menawarkan etika kepedulian sebagai salah satu sumber jawaban yang tepat (Noddings, 2013a; Noddings, 2010b).

\section{2. $\quad$ Kondisi-kondisi yang Perlu dan Memadai bagi Terwujudnya Toleransi Antaragama}

Paparan di atas menegaskan dua hal penting yang akan menjadi fokus pembahasan bagian ini. Pertama, dialog antarpemeluk agama di Indonesia menyisakan agenda besar, yakni memperbanyak ruang perjumpaan. Uraian mengenai perubahan subjek dialog dari yang berpusat pada pemerintah (top-down) kepada melibatkan masyarakat akar rumput menegaskan pentingnya ruang perjumpaan. Upaya memperbanyak ruang perjumpaan sama artinya dengan memperbesar kesempatan untuk saling bertemu, berinteraksi dengan sesama warga dari kelompok agama yang berbeda demi terwujudnya kehidupan bersama sebagai saudara. Pentingnya ruang perjumpaan itu dapat dirumuskan secara sederhana lewat kata-kata seorang Pendeta dari Jawa Timur berikut.

"Salah satu bentuk membiasakan diri itu adalah kita harus berani keluar dari zona nyaman kita, supaya kalau bicara nyaman juga ngomong nyamannya orang lain, lalu juga menjadi penting bahwa membiasakan diri bertemu, berbicara, dan di situ kita semakin hari akan semakin mengikis prasangka kita. Itu yang saya bilang menghidupi perbedaan itu sebenarnya seperti itu, justru orang harus keluar dari cangkang dirinya" (Riski, 2019).

Kedua, kita bisa belajar dari Martin Buber (Buber, 2002), bahwa setiap perjumpaan tidak otomatis menghasilkan dialog, saling pengertian, dan persaudaraan. Selalu ada dua kemungkinan dalam setiap perjumpaan, yakni terbentuknya relasi dialogal di satu pihak dan relasi tanpa dialog alias monolog di lain pihak. Relasi yang dialogal berpotensi menghasilkan suatu dialog yang otentik atau suatu dialog teknis.

Perjumpaan dapat membentuk dialog yang otentik jika setiap individu tidak hanya menyadari kehadiran dirinya, tetapi juga kehadiran yang lain sebagai pribadi yang sedang mengarahkan dirinya dengan maksud untuk membangun sebuah relasi timbal-balik. Dialog otentik dalam perjumpaan itu dapat terjadi baik melalui bahasa maupun dalam keheningan (tanpa kata terucap). Sebaliknya, dialog teknis terjadi ketika peserta dialog memusatkan perhatiannya pada upaya menemukan pemahaman yang objektif. Dialog teknis cenderung 
mengobjekkan. Sementara itu, ruang perjumpaan yang menghadirkan individu-individu yang memusatkan perhatian pada kepentingannya dan berbicara hanya kepada dirinya akan berakhir pada monolog (Buber, 2002).

Dialog antaragama tidak akan melahirkan kehidupan bersama yang harmonis jika tidak ada perjumpaan antarkelompok yang berbeda. Perjumpaan hanya akan melahirkan monolog atau mungkin dialog teknis jika tidak/belum tercipta kondisi-kondisi yang diprasyaratkan sebagai basis terjadinya dialog otentik. Merujuk ke pemikiran Nel Noddings mengenai etika kepedulian, Peneliti mengajukan lima kondisi sebagai syarat terwujudnya perjumpaan dan dialog antarumat beragama (Noddings, 2013a; Noddings, 2010b).

Pertama, sikap afirmatif. Individu yang terlibat dalam perjumpaan adalah pribadi yang rentan (vulnerable), dapat terluka, berpotensi disakiti, dilukai, dan menjadi korban. Kerentanan ini berhubungan dengan kemungkinan setiap orang untuk saling mengobjekkan, apa yang oleh Martin Buber dikategorikan sebagai relasi "aku-benda" (I-It). Kemungkinan ini ada karena setiap individu menyadari adanya perbedaan sekaligus menetapkan jarak sebagai upaya menegaskan identitas. Meskipun demikian, kesadaran akan kuatnya potensi kesalingan yang rentan (vulnerable reciprocity) - setiap orang berpotensi terluka dan hancur - dapat mendorong orang untuk berbuat baik (Noddings, 2013). Itulah sebabnya mengapa subjek dalam setiap perjumpaan bersedia mengambil sikap berbuat baik sebagai preferensi moralnya. Simone Weil melukiskannya secara sangat baik, katanya:

"Di lubuk hati setiap manusia, sejak dari masa bayi paling awal sampai telah masuk ke liang lahat, ada sesuatu yang terus-menerus diharapkan, di dalam semua pengalaman kejahatan yang dilakukan, diderita, atau yang dia sendiri menjadi saksi, bahwa kebaikanlah dan bukan kejahatan yang akan terjadi padanya. Inilah pengharapan yang suci dalam diri setiap insan yang melampaui segala yang lainnya (Weill, 2005, hlm. 51).

Kedua, perasaan rentan, mudah terluka dan hancur ini hanya bisa lahir dari kesadaran keibuan yang senantiasa peduli, merawat dan yang bersedia mengesampingkan agenda pribadinya demi memastikan anakanaknya selamat. Hanya dalam disposisi seperti inilah relasi antarindividu beralih dari kecenderungan mengobjekkan kepada kepedulian (caring). Para pembela etika kepedulian yakin, bahwa jauh sebelum lahirnya kepedulian etis (kewajiban untuk peduli dan berbuat baik kepada orang lain), kepedulian alamiah telah lebih dahulu eksis sebagai sumber moral yang mendorong tindakan berbuat baik. Inilah kepedulian alamiah yang lahir dari hati seorang ibu yang tidak pernah ingin mencelakakan anak-anaknya.

Ketiga, relasi berkepedulian hanya mungkin terealisasi jika setiap orang yang terlibat dalam suatu perjumpaan memiliki sikap "perhatian” (attention). Sikap empati yang mengarah kepada tindakan berbuat baik (misalnya menolong orang yang sakit, kelaparan, dan sebagainya) hanya dapat terwujud jika individu terlebih dahulu memiliki kemampuan memerhatikan (attention). Perhatian dalam pemahaman Nel Noddings adalah sikap peka tidak hanya terhadap kehadiran orang lain, tetapi pada keseluruhan diri, kebutuhan, kegundahan dan kebahagiaan orang itu.

Perhatian itu mewujud dalam cinta penuh perhatian (attentive love). Jenis cinta ini muncul dari dorongan untuk menolong, melindungi, merawat dan memastikan individu yang dengannya dia berelasi tidak rusak atau 
binasa. Itulah sebabnya mengapa Nel Noddings memosisikan cara berpikir keibuan (maternal thinking) sebagai sumber moral dan bukan pemikiran rasional-imparsial (rational thinking). Berbeda dari pemikiran rasional yang selalu berusaha mengambil jarak dan mengobjekkan, cara berpikir keibuan mementingkan relasi konkret. Berpikir keibuan membenamkan individu yang peduli dalam setiap relasi dan memampukannya "merasa bersama" (feeling with) (Noddings, 2010a).

Keempat, sikap penuh perhatian yang membenamkan individu berkepedulian dalam relasi dengan orang lain mensyaratkan kondisi lain yang disebut Nel Noddings sebagai pelucutan motivasi diri (motivational displacement). Kepedulian akan sulit terealisasi dalam relasi dengan orang yang tidak memiliki hubungan darah. Dalam arti itu, sikap pelucutan motivasi menjadi lebih relevan pada level kepedulian etis, yakni kepedulian terhadap subjek moral di luar hubungan darah (relasi orang tua dengan anak, dengan keluarga inti, dengan keluarga besar, dan sebagainya). Padahal sudut pandang, kepentingan, persepsi, agenda pribadi, bahkan pengaruh sosial, budaya, agama ikut mewarnai setiap perjumpaan (Noddings, 2013). Dalam situasi demikian, pelucutan kepentingan diri menjadi tuntutan yang niscaya.

Pelucutan kepentingan diri sebenarnya adalah tuntutan untuk menanggalkan segala agenda, asumsi, rasa senang tidak senang subjektif, prasangka, termasuk juga relasi subjek-objek, relasi atasan-bawahan, relasi orang yang lebih berkuasa dengan mereka yang tak punya kekuasaan, bahkan relasi ogah-ogahan dengan orang lain karena rasa capai, malas, bosan, kelelahan bekerja, dan semacamnya. Pelucutan motivasi dari kepedulian terjadi secara alamiah karena kemampuan responsif Si Pemeduli terhadap Si Terpeduli. Si Pemeduli yang mengambil bagian secara penuh dalam tindakan memedulikan akan senantiasa ditopang dan diperkuat, dan tindakan kepeduliannya tidak akan memburuk ke keadaan yang dirasakan sebagai membebani (Noddings, 2013).

Bagi Nel Noddings, pelucutan motivasi dan kepentingan diri sebenarnya adalah upaya menyingkirkan berbagai agenda pribadi demi mencurahkan perhatian pada dan mengusahakan kebaikan orang yang dipedulikan. Meskipun tidak mudah dilakukan, itu tidak berarti bahwa tidak perlu dipraktikkan. Jika model ideal relasi berkepedulian adalah perhatian seorang ibu kepada anak-anaknya, sifat seperti merasa bahagia dan bersukacita menyambut kehadiran orang lain (receptive joy) harus diposisikan sebagai prasyarat. Perhatikan bahwa Nel Noddings membedakan receptive joy dari reflective joy. Jika reflective joy adalah rasa gembira yang diperoleh setelah seseorang merefleksikan suatu tindakannya, receptive joy adalah pengalaman kegembiraan "alamiah" yang dirasakan dan dirayakan ketika seseorang sedang berada di tengah-tengah orang lain yang dengannya dia berelasi. Itulah pengalaman yang tidak berjarak, yang meleburkan Si Pemeduli dan Si Terpeduli dalam sebuah "sukacita” bersama (Noddings, 2013).

Kelima, relasi berkepedulian dengan orang lain berdasarkan kondisi-kondisi yang diprasyaratkan di atas tidak bermakna apa-apa jika orang lain yang dengannya kita berelasi tidak memberi tanggapan. Padahal tanda bahwa orang yang dipedulikan itu tidak diobjekkan, kepentingan dan kesejahteraannya diutamakan, dan terbuka kepada kehidupan bersama sebagai saudara jika Si Terpeduli mengekspresikan sikap pengakuan (recognition). Wujud konkret sikap ini tidak terbatas pada pengakuan bahwa dirinya telah dipedulikan, tetapi 
juga ucapan terima kasih atas seluruh tindakan baik yang telah diarahkan kepadanya. Pengakuan tidak harus dalam bentuk ungkapan terima kasih, tetapi bisa juga melalui bahasa tubuh atau kesediaan untuk terlibat aktif serta menikmati relasi tersebut, keterbukaan untuk bertumbuh bersama, pelibatan (inclusion) serta ekspresi kehangatan yang mendalam (Noddings, 2013).

\section{Kesimpulan}

Peneliti telah menggali berbagai data dan informasi untuk "membuktikan" pentingnya etika kepedulian, terutama perhatian, sebagai kondisi yang niscaya bagi perjumpaan dan kerja sama antarumat beragama. Seluruh argumentasi tulisan ini dibangun berdasarkan dua pertimbangan utama. Pertama, kehidupan bersama sebagai saudara tidak mungkin terwujud tanpa perjumpaan. Karena itu, Peneliti mengikuti pendapat banyak pihak soal pentingnya memperluas ruang perjumpaan. Kedua, agar perjumpaan itu terjadi tanpa saling mengobjekan dalam arti berelasi demi merealisasikan kepentingan diri atau kelompok, dibutuhkan terciptanya kondisi-kondisi tertentu sebagai syarat. Peneliti kemudian menawarkan lima kondisi yang wajib ada dalam perjumpaan dan dialog antaragama berdasarkan pembacaan atas pemikiran Nel Noddings mengenai etika kepedulian.

Perjumpaan dan dialog antarumat beragama dalam konteks etika kepedulian mengandaikan inisiatif warga negara untuk keluar dari kenyamanan dan kepentingan dirinya supaya bisa berjumpa dengan orang lain yang berbeda. Dalam arti itu, pendekatan dialog yang sifatnya legal dan formal tidak hanya kurang relevan tetapi juga berpotensi menjadi penghalang bagi terbentuknya relasi yang berkepedulian, terutama menguatnya penekanan pada dimensi perbedaan karena pilihan fokus pada narasi-narasi yang lebih doktriner. Dalam situasi demikian, pentingnya kepekaan sebagai syarat memahami orang lain secara lebih mendalam (attentive love) berpotensi terabaikan.

Meskipun demikian, pendekatan sistemik tetap dibutuhkan, dan ini adalah poin rekomendasi Peneliti. Peregulasian kehidupan bersama lewat pengarusutamaan penegakan hukum atas ujaran kebencian, penghinaan, dan penonjolan ajaran agama sendiri dengan merendahkan dan/atau menyerang ajaran agama lain dapat membantu penciptaan ruang hidup bersama yang harmonis. Selain itu, ruang perjumpaan yang semakin sempit karena eksklusivisme ruang sosial berdasarkan agama atau etnisitas seharusnya dihentikan dengan meregulasi (kembali) berbagai aturan soal pemukiman, perumahan, pembangunan apartemen, dan semacamnya.

Kekuatan etika kepedulian sebagai fondasi bagi kehidupan bersama terletak pada dorongan alamiah untuk memedulikan orang lain dan "memastikan" bahwa dia tidak terluka, tidak tersakiti dan tidak mati. Dorongan itu memang berasal dari insting keibuan yang spontan, pertama-tama karena perasaan rapuh timbalbalik. Meskipun demikian, dorongan ini diharapkan semakin melingkupi sebanyak-banyaknya orang di luar hubungan kekerabatan. Dalam konteks dialog antarumat beragama di Indonesia, cita-cita etis ini masih jauh panggang dari api. Sebagiannya disebabkan oleh hilangnya insting keibuan sebagai akibat dari memudarnya berbagai kondisi sebagaimana telah dideskripsikan dalam tulisan ini. 
Tidak ada jalan lain yang lebih efektif untuk memulai perjumpaan dan dialog antarumat beragama selain keberanian mengambil langkah pertama: keluar dari diri, kehidupan dan kenyamanan diri agar bisa berjumpa dengan orang lain, mereka yang berpotensi menjadi terluka dan hancur seperti kita juga.

\section{Daftar Pustaka}

Ali, M., Hum, M., Kastolani, E. D., \& Ag, M. (2019). Harmonical Communication: Sebuah Pesan Damai dalam Perbedaan. (Kastolani, Ed.). Salatiga: LP2M-Press.

Amindoni, A. (2019). Perumahan dan permukiman syariah: Ancaman bagi toleransi dan budaya lokal? Retrieved August 5, 2019, from https://www.bbc.com/indonesia/majalah-49353757

Anwar, M. K. (2018). Dialog Antar Umat Beragama di Indonesia: Perspektif A. Mukti Ali. Jurnal Dakwah, 19(1), 89-107.

Assyaukanie, L. (2018). Akar-Akar Legal Intoleransi dan Diskriminasi di Indonesia. MAARIF Journal , 13(2), $27-42$.

Banawiratma, J. ., \& Bagir, Z. A. (2010). Dialog Antarumat Beragama: Gagasan dan Praktik di Indonesia (1st ed.). Jakarta: Mizan Publika.

Buber, M. (2002). Between Man and Man (1st ed.). New York: Routledge \& Kegan Paul.

Casram, C. (2016). Membangun Sikap Toleransi Beragama dalam Masyarakat Plural. Wawasan: Jurnal Ilmiah Agama Dan Sosial Budaya, 1(2), 187-198.

Creel, R. E. (2001). Thinking Philosophically: An Introduction to Critical Reflection and Rational Dialogue (2nd ed.). Massachusetts: Blackwell Publisher Inc.

Erdianto, K. (2018). Konflik dan Pelanggaran HAM: Catatan Kelam 20 Tahun Reformasi. Retrieved August 15, 2019, from https://nasional.kompas.com/jeo/konflik-dan-pelanggaran-ham-catatan-kelam-20-tahunreformasi

Fadel. (2019). Semangat Toleransi, FKUB Akan Gelar Kemah Lintas Agama. Retrieved August 10, 2019, from http://liputanislam.com/berita/semangat-toleransi-fkub-kulonprogo-akan-gelar-kemah-lintasagama/

Hakim Saifuddin, L., Mas'ud, A., Fathurahman, O., Adlin Sila, M., Farida, A., Wahab, A. J., ... Fahrul, F. (2019). Moderasi Beragama. Jakarta: Kementerian Agama RI.

Irham, A. (2017). Islam dan Pembauran Sosial: Rekonstruksi Fenomena Multikulturalisme. Journal of Islamic \& Social Studies, 1(2), 155-164.

Ismail, N. (2016). Menggantung Asa Kepada Forum Kerukunan Umat Beragama. In Khudzaifah Dimyati, Achmad Nurmandi, M. Nurul Yamin, \& Sudarno Shobron (Eds.), Konferensi Nasional ke-4 Asosiasi Program Pascasarjana Perguruan Tinggi Muhammadiyah (pp. 149-158). Yogyakarta: Program Pascasarjana Universitas Muhammadiyah.

Jena, Y. (2016). Watak Kepedulian dalam Kepemimpinan Walikota Surabaya, Tri Rismaharini. Jurnal Perkotaan, 8(1), 36-48.

Kemal Fasya, T. (2016, December 31). Keberagaman. Kompas, p. 7. Retrieved from https://epaper.kompas.id/baca/kompaspagi/20161231

Kuncahyono, T. (2016, January 31). Kredensial. Kompas, p. 4.

Lubis, R. (2016). Kerukunan Beragama dalam Cita dan Fakta. Jakarta: Pusat Kerukunan Umat Beragama.

Magrini, J. M. (2018). Plato's Socrates, Philosophy and Education. New York: Springer International Publishing.

Mantu, R. (2018). Lembaga Interfaith di Indonesia: Studi Kritis Pendekatan Formalistik Negara Terhadap Kerukunan Antarumat Beragama. Aqlam: Journal of Islam and Plurality, 1(1), 53-64.

Mudzakkir, A. (2017). Konservatisme Islam dan Intoleransi Keagamaan di Tasikmalaya. Harmoni., 16(1), 5774.

Naim, N. (2016). Abdurrahman Wahid: Universalisme Islam dan Toleransi. KALAM, 10(2), 423-444.

Noddings, N. (2010a). Complexity in caring and empathy. Abstracta, V(Special Issue), 6-12.

Noddings, N. (2010b). The Maternal Factor: Two Paths to Morality. California: University of California Press.

Noddings, N. (2013). Caring: A Relational Approach to Ethics and Moral Education (3rd ed.). California: University of California Press.

Pusat Data dan Statistik Pendidikan dan Kebudayaan. (2017). Analisis Faktor-faktor yang Memengaruhi SIkap Toleransi di Indonesia. Jakarta.

Riski, P. (2019). Perbanyak Ruang Perjumpaan untuk Perkuat Kerukunan Umat Beragama. Retrieved August 
12, 2019, from https://www.voaindonesia.com/a/perbanyak-ruang-perjumpaan-untuk-perkuatkerukunan-umat-beragama/4795592.html

Rogers, B., \& Flipse, S. (2014). Indonesia: Pluralism in Peril. The rise of religious intolerance across the archipelago. Surrey. Retrieved from https://www.csw.org.uk/2014/02/14/report/179/article.htm

Safira Taylor, G. (2018). Wahid Foundation: Perempuan Lebih Toleran daripada Laki-laki. Retrieved August 10, 2019, from https://www.cnnindonesia.com/nasional/20180129200959-32-272455/wahidfoundation-perempuan-lebih-toleran-daripada-laki-laki

Sholikin, A. (2018). Intoleransi, Radikalisme, dan Terorisme di Lamongan. Polinter , 4(1), 1-20.

Sirait, M. O. B. (2017). Peran Forum Kerukunan Umat Beragama Dalam Mengembangkan Nilai Toleransi Di Kabupaten Bekasi. Unnes Civic Education Journal , 3(2), 10-17.

Sultoni, \& Darojat Ariyanto, M. (2017). Peran Muhammadiyah Dalam Toleransi Antar Umat Beragama Di Desa Bandardawung Kecamatan Tawangmangu Kabupaten Karanganyar Periode 2013-2018. Universitas Muhammadiyah Surakarta. Retrieved from http://eprints.ums.ac.id/50049/

SUSENAS. (2014). Survei Sosial Ekonomi Nasional. Jakarta. Retrieved from https://sirusa.bps.go.id/sirusa/index.php/dasar/pdf?kd=1558\&th=2014

Syambudi, I. (2019). Perumahan Khusus Muslim dan Ancaman Toleransi di Yogyakarta. Retrieved August 5, 2019, from https://tirto.id/perumahan-khusus-muslim-dan-ancaman-toleransi-di-yogyakarta-dl1D

Wahid, Y. Z., Vulovik, V., Subhi Azhari, M., Ferdhi, G., Dja'far, A., Irawan, A., \& Nisa, N. (2015). Laporan Kebebasan Beragama dan Berkeyakinan (KBB). Jakarta. Retrieved from https://media.neliti.com/media/publications/45149-ID-laporan-kebebasan-beragama-dan-berkeyakinankbb-2015.pdf

Weill, S. (2005). Simone Weil: An Antology. (Sian Miles, Ed.) (2nd ed.). London: Penguin Classics. 